\title{
Total IgG Antibody Secreting Cell Count
}

National Cancer Institute

\section{Source}

National Cancer Institute. Total Ig G Antibody Secreting Cell Count. NCI Thesaurus. Code C120624.

The determination of the number of IgG antibody secreting cells present in a sample. 